\title{
KRT13 wt Allele
}

National Cancer Institute

\section{Source}

National Cancer Institute. KRT13 wt Allele. NCI Thesaurus. Code C107626.

Human KRT 13 wild-type allele is located in the vicinity of $17 q 21.2$ and is approximately 5 $\mathrm{kb}$ in length. This allele, which encodes keratin, type I cytoskeletal 13 protein, plays a role in epidermal development. Mutation of the gene is associated with white sponge nevus. 